\title{
Analisis Pengaruh Penggunaan Game Edukasi pada Penguasaan Kosakata Bahasa Asing dengan Studi Kasus Game Edukasi Bahasa Arab
}

\author{
Muhammad Shulhan Khairy ${ }^{1 *}$, Darlis Herumurti ${ }^{1}$, Imam Kuswardayan ${ }^{1}$ \\ ${ }^{1}$ Jurusan Teknik Informatika, Fakultas Teknologi Informasi \\ Institut Teknologi Sepuluh Nopember \\ *al.khair.21@gmail.com
}

\begin{abstract}
ABSTRAK
Pemanfaatan game saat ini telah merambah ke berbagai bidang, salah satunya adalah bidang edukasi. Pada penelitian ini dilakukan analisis pengaruh game edukasi pada kemampuan menguasai kosakata bahasa asing, dengan studi kasus bahasa Arab. Game edukasi tersebut menggunakan perangkat bergerak dan salah satunya menggunakan teknologi realitas virtual dengan kakas Google Cardboard. Game edukasi diujikan pada pengguna berusia 10-15 tahun dan dibagi menjadi dua kelompok, berdasarkan teknologi yang digunakan dan genre game. Pengguna melakukan pre-test dan post-test untuk mengukur kemampuan mereka sebelum dan sesudah mengujikan game. Hasil pengujian tersebut dianalisis dengan metode uji hipotesis ANOVA. Dari kedua kelompok tersebut didapatkan kesimpulan bahwa perbedaan teknologi tidak berpengaruh secara signifikan terhadap kemampuan pengguna. Pada kelompok kedua, didapatkan kesimpulan bahwa faktor jenis game, faktor jenis kelamin pengguna, dan gabungan kedua faktor tersebut tidak berpengaruh secara signifikan terhadap perubahan kemampuan pengguna dalam menguasai perbendaharaan kosakata Bahasa Arab.
\end{abstract}

Kata kunci : bahasa asing; game edukasi; realitas virtual

\section{Pendahuluan}

Industri game merupakan salah satu industri yang memiliki pengguna yang cukup banyak. Pada tahun 2015, lebih dari 150 juta orang di Amerika Serikat menjadi pengguna game. Dari jumlah tersebut, 42 persennya memainkan game minimal 3 jam dalam satu pekan. Jumlah pengguna yang cukup banyak berdampak pada sisi ekonomi. Pada tahun 2014, 22 miliar US dolar dihasilkan dari industri ini dengan penjualan lebih dari 135 juta buah game [1]. Fakta tersebut menggambarkan bahwa industri game adalah industri yang cukup besar dari sisi pengguna maupun penghasilan yang didapatkan oleh para pelaku industri game.

Game adalah salah satu sarana untuk mengisi waktu luang dan melepas penat, namun saat ini perkembangan dunia game telah merambah pada bidang selain hiburan. Game telah dimanfaatkan untuk sarana edukasi, militer, bahkan pemasaran dan periklanan produk [2]. Penelitian oleh [2] mengisyaratkan bahwa pendidikan menjadi salah satu bidang pemanfaatan pengembangan game. Hal tersebut lebih sering disebut sebagai game edukasi.
Pemanfaatan game edukasi telah diimplementasikan pada berbagai bidang edukasi. Penelitian tentang pengembangan game edukasi telah dilakukan salah satunya pada game edukasi bidang sejarah yang digunakan untuk meningkatkan motivasi siswa [3]. Selain itu juga dilakukan penelitian tentang dampak diterapkannya game untuk meningkatkan motivasi siswa sekolah dasar dalam pembelajaran geografi [4]. Selain digunakan untuk bidang geografi, penggunaan game juga terdapat pada bidang edukasi sains [5]. Pada penelitian tersebut dilakukan review terhadap artikel ilmiah yang membahas tentang implementasi simulasi dalam edukasi sains yang meliputi topik antara lain tentang genetika, teori sel, mesin elektrik, efek fotoelektrik, analisa kromosom, elektronika analog, sirkuit elektrik, dan lensa optik. Selain itu game edukasi juga dapat dijadikan sarana untuk ranah edukasi bahasa. Pada penelitian [6] dilakukan penggunaan game edukasi untuk mengenalkan kosakata bahasa asing pada siswa di Iran. Bahasa asing yang mereka gunakan adalah bahasa Inggris, sebagai mata pelajaran bahasa asing secara umum untuk siswa Iran. 
Aspek penggunaan teknologi dalam game menjadi pendukung bagi pengguna untuk tetap memainkan game yang ada. Kemudahan penggunaan smartphone menjadi sarana untuk mendukung pengembangan teknologi yang digunakan untuk game edukasi. Teknologi yang berkembang saat ini adalah augmented reality yang termasuk dalam ranah realitas virtual. Teknologi augmented reality telah digunakan untuk mengenalkan berbagai bentuk objek pada anak-anak usia dini, dengan kisaran usia 5-6 tahun [7]. Augmented reality digunakan untuk mengenalkan bentuk benda, angka, hewan, sayuran, kendaraan, profesi, dan warna. Mereka memberi nama permainan tersebut sebagai Educational Magic Toys (EMT). Selain itu angmented reality juga telah dimanfaatkan pada game edukasi untuk mengenalkan organ tubuh manusia [8]. Selain augmented reality, teknologi realitas virtual lainnya juga dapat digunakan sebagai pendukung game edukasi. Salah satu teknologi terkini adalah penggunaan Google Cardboard, sebagai alternatif alat yang terjangkau dan dapat digunakan oleh banyak orang karena cukup dengan smartphone, pengguna dapat memainkan permainan dengan teknologi realitas virtual.

Penulis mendapati penelitian tentang jenis game yang paling diminati berdasarkan parameter jenis kelamin (gender) penggunanya. [3] Penelitian tersebut mengambil sampel anak-anak usia pra-remaja, yaitu rentang usia 10-15 tahun. Metode yang digunakan adalah dengan melakukan survei dengan jumlah 213 orang dengan komposisi 119 anak laki-laki dan 94 anak perempuan. Jenis game yang dimasukkan kedalam survei adalah first person shooter (FPS), fighting, sports, virtual life, massively multi player online role playing game (MMORPG), puzzle, role playing game, dan party. Hasil yang didapatkan adalah game dengan jenis FPS dengan jumlah 92, fighting dengan jumlah 66, dan sports dengan jumlah 46 yang paling disukai oleh anak laki-laki dan game jenis virtual life dengan jumlah 49, fighting dengan jumlah 35, dan puzzle dengan jumlah 34 yang paling disukai oleh anak perempuan [9].

Dari literatur diatas, terdapat aspek yang cukup menarik untuk diteliti, yaitu adanya perkembangan teknologi pada game dan adanya kecondongan pengguna terhadap jenis game pada masing-masing jenis kelamin pengguna. Sehingga pada penelitian ini akan dikaitkan dengan pemanfaatan game dalam bidang edukasi. Bidang edukasi bahasa asing, secara khusus bahasa Arab yang merupakan pelajaran yang dirasa cukup sulit untuk dipahami oleh siswa.

Dalam penelitian ini dilakukan pengembangan game edukasi untuk pengenalan kosakata bahasa asing, yaitu bahasa Arab dengan perbandingan teknologi yang digunakan dan tipe gameplay berdasarkan jenis kelamin dari pengguna. Langkah pertama yang dilakukan adalah pengembangan prototipe game inti (main game) untuk pengenalan kosakata bahasa asing. Pengembangan ini dibagi menjadi dua kelompok. Pengembangan pada kelompok pertama, akan dilakukan pengembangan dua tipe sesuai jenis teknologi yang akan digunakan, yaitu pada perangkat bergerak tanpa kakas realitas virtual dan dengan kakas realitas virtual. Pengembangan pada kelompok kedua adalah tiga jenis game dengan genre yang berbeda, yaitu FPS, fighting, dan virtual life. Ketiga genre tersebut adalah genre yang diminati pengguna berdasarkan jenis kelamin pengguna. FPS adalah genre yang paling diminati oleh pengguna laki-laki, virtual life adalah genre yang paling diminati oleh pengguna perempuan, dan fighting sebagai genre yang paling diminati oleh kedua jenis kelamin pengguna. Dari game yang dibuat dilakukan pengujian terhadap siswa usia 10-15 tahun untuk menganalisis signifikansi pengaruh teknologi yang digunakan dan jenis game terhadap kemampuan penguasaan kosakata bahasa Arab.

\section{Metode}

\section{A. Deskripsi Umum}

Game yang dikembangkan dibagi menjadi beberapa jenis berdasarkan unsur yang diteliti. Dalam skema pada Gambar 1 terdapat 5 macam prototipe game dengan pembagian dua kelompok. Kelompok pertama adalah game yang menggunakan teknologi VR, kelompok yang kedua adalah game dengan genre favorit berdasarkan jenis kelamin pengguna. Jenis game fighting sebagai game yang diminati oleh pengguna laki-laki dan perempuan, jenis game FPS sebagai game yang diminati oleh pengguna laki-laki, dan jenis game virtual life sebagai game yang diminati oleh pengguna perempuan.

Unsur edukasi pada sistem yang dibangun adalah kosakata benda-benda yang ditemui sehari-hari dalam bahasa arab. Diharapkan unsur edukasi yang mengambil unsur kosakata bahasa arab dapat memberikan kemudahan untuk mengenali, mengingat, dan menambah perbendaharaan kosakata. Kosakata yang akan disertakan dalam penelitian ini adalah buku, pulpen, pensil, spidol, penggaris, penghapus papan tulis, penghapus, meja, kursi, papan tulis, jam dinding, lemari, rak buku, cermin, lukisan, peta, jendela, gelas, cangkir, piring, sendok, garpu, tas ransel, kasur, pintu, kompor, lampu, pisau, sepatu, alpukat, anggur, papaya, nanas, melon, mangga, pisang, apel, jeruk, semangka, dan tomat.

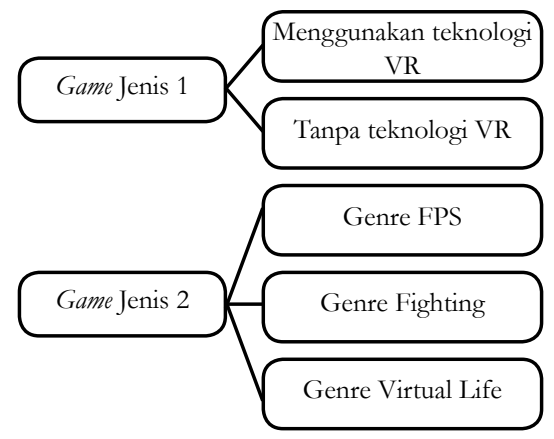

Gambar 1. Skema deskripsi umum penelitian

\section{B. Metode Pengujian}

Pengujian dilakukan pada pengguna dengan rentang usia 10-15 tahun. Terdapat dua metode untuk pengambilan sampel, yaitu between subjects dan within subjects 
[10]. Penelitian ini menggunakan metode within subjects. Sebelum melakukan pengujian game, pengguna mengisi terlebih dahulu soal pre-test, yaitu arti kosakata bahasa Arab untuk mengukur pemahaman awal. Setelah melakukan pengujian terhadap game yang dikembangkan, diambil data post-test dimana pengguna menjawab soal yang sama dengan ketika pre-test untuk menguji pemahaman setelah mengujikan game. Soal pre-test dan post-test adalah seperti yang tertera pada Tabel 1. Dari nilai kedua tes tersebut dapat dilihat perubahan kemampuan pengguna sebelum dan setelah menguikan game. Gameplay masing-masing kelompok pengguna dapat dilihat pada Gambar 2 dan Gambar 3.

Setelah itu dihitung selisih nilai antara post-test dengan pre-test, selisih nilai tersebut dirata-rata dan digunakan untuk analisis menggunakan metode ANOVA (Analysis of Variance) berdasarkan jenis game yang diujikan. ANOVA adalah metode uji hipotesis yang cepat dan beresiko mengandung kesalahan yang lebih kecil [11]

Kelompok pertama dibagi berdasarkan jenis game yang menggunakan teknologi realitas virtual dan tidak menggunakan teknologi realitas virtual. Desain pengujian dapat dilihat pada Tabel 2. Dalam tabel tersebut terdapat 8 pengguna, yaitu sebagai kelipatan dari faktor yang diujikan berjumlah dua buah. Huruf A sebagai simbol untuk game yang menggunakan teknologi realitas virtual, huruf B sebagai simbol untuk game yang tidak menggunakan teknologi realitas virtual. Pada tabel tersebut, pengguna nomor 1 hingga 4 melakukan pengujian pada game yang menggunakan teknologi realitas virtual terlebih dahulu, kemudian mengujikan game yang tidak menggunakan teknologi realitas virtual. Sebaliknya, pada pengguna nomor 5 hingga 8 mengujikan game yang tidak menggunakan teknologi realitas virtual terlebih dahulu, kemudian mengujikan game yang menggunakan teknologi realitas virtual.

Tabel 1. Soal pre-test dan post-test

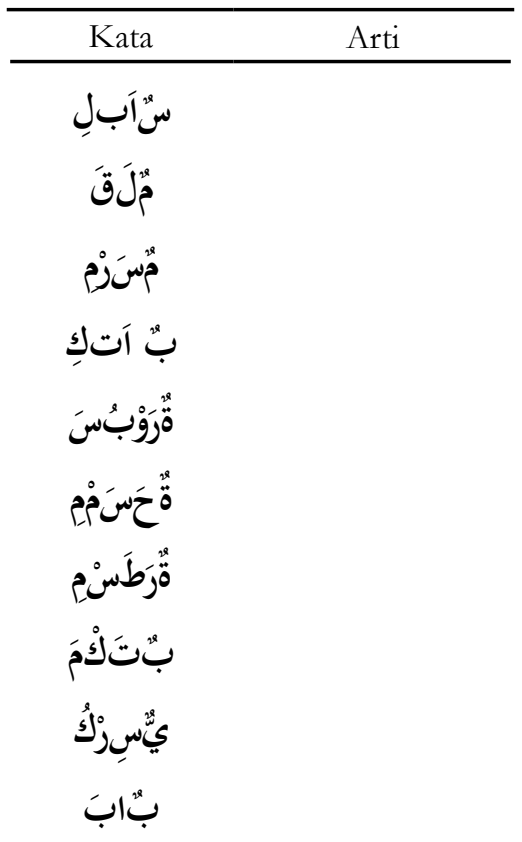

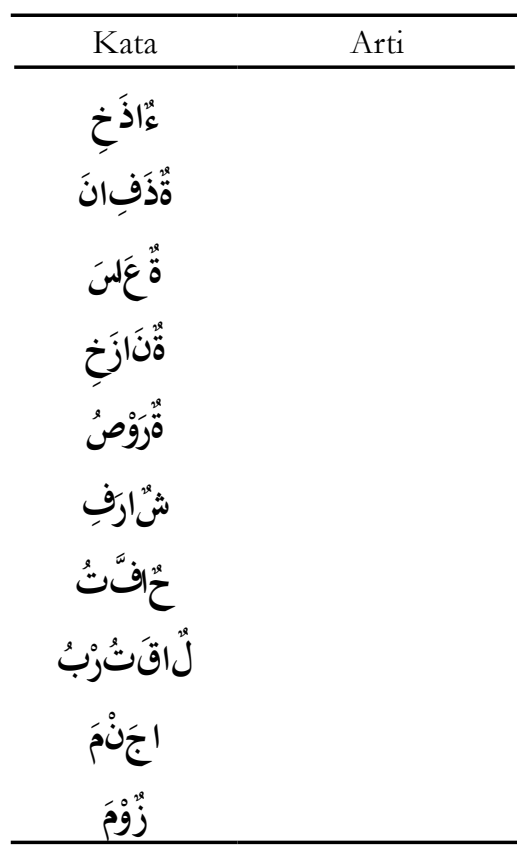

Pada kelompok pertama ditetapkan hipotesis sebagai berikut:

$\mathrm{H}_{0}$ : tidak ada perbedaan nilai dari kedua perlakuan berdasarkan jenis game

$\mathrm{H}_{1}$ : ada perbedaan nilai dari kedua perlakuan berdasarkan jenis game

Kelompok kedua dibagi berdasarkan jenis game. Pada kelompok kedua terdapat tiga jenis game yaitu FPS, fighting, dan virtual life. Pengambilan sampel pengguna pada ketiga jenis tersebut menggunakan metode within subjects dengan jumlah pengguna laki-laki dan perempuan yang sama pada masing-masing jenis game. Desain skenario pengujian dapat dilihat pada Tabel 3. Pada tabel tersebut, pengguna dengan nomor 1 hingga 4 mengujikan game dengan jenis FPS terlebih dahulu, kemudian game dengan jenis fighting, lalu game dengan jenis virtual life. Pengguna dengan nomor 5 hingga 8 mengujikan game jenis fighting terlebih dahulu, kemudian mengujikan game virtual life, dan terakhir game FPS. Pengguna dengan nomor 9 hingga 12 mengujikan game virtual life terlebih dahulu, kemudian mengujikan game FPS, dan terakhir mengujikan game fighting. Hipotesis pada kelompok kedua dengan faktor perlakuan perbedaan jenis game adalah berikut:

$\mathrm{H}_{0}$ : tidak ada perbedaan pada perkembangan nilai pengguna dengan perbedaan jenis game

$\mathrm{H}_{1}$ : terdapat perbedaan pada perkembangan nilai pengguna dengan perbedaan jenis game

Selanjutnya hipotesis pada faktor jenis kelamin pengguna sebagai berikut:

$\mathrm{H}_{0}$ : tidak ada perbedaan signifikan pada perkembangan nilai pengguna dengan perbedaan jenis kelamin pengguna

$\mathrm{H}_{1}$ : terdapat perbedaan signifikan pada perkembangan nilai pengguna dengan perbedaan jenis kelamin pengguna 
Hipotesis keterkaitan antara faktor jenis kelamin pengguna dan jenis game adalah berikut:

$\mathrm{H}_{0}$ : jenis game tidak bergantung pada jenis kelamin pengguna atau jenis kelamin pengguna tidak bergantung pada jenis game terhadap hasil perubahan nilai pengguna

$\mathrm{H}_{1}$ : jenis game bergantung pada jenis kelamin pengguna atau jenis kelamin pengguna bergantung pada jenis game terhadap hasil perubahan nilai pengguna

Tabel 2. Desain pengujian kelompok pertama

\begin{tabular}{clc}
\hline Pengguna & \multicolumn{2}{l}{ Perlakuan } \\
\hline 1 & A & B \\
2 & A & B \\
3 & A & B \\
4 & A & B \\
5 & B & A \\
6 & B & A \\
7 & B & A \\
8 & B & A \\
\hline
\end{tabular}

Tabel 3. Desain pengujian kelompok kedua

\begin{tabular}{cccc}
\hline Pengguna & \multicolumn{3}{c}{ Perlakuan } \\
\hline 1 & A & B & C \\
2 & A & B & C \\
3 & A & B & C \\
4 & A & B & C \\
5 & B & C & A \\
6 & B & C & A \\
7 & B & C & A \\
8 & B & C & A \\
9 & C & A & B \\
10 & C & A & B \\
11 & C & A & B \\
12 & C & A & B \\
\hline
\end{tabular}
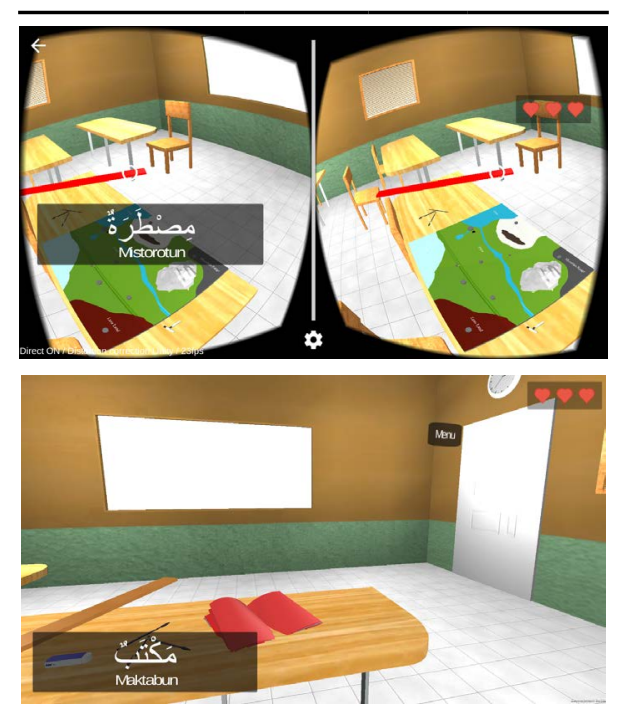

Gambar 2. Gameplay pada kelompok pertama. Atas: menggunakan VR, bawah: tanpa VR
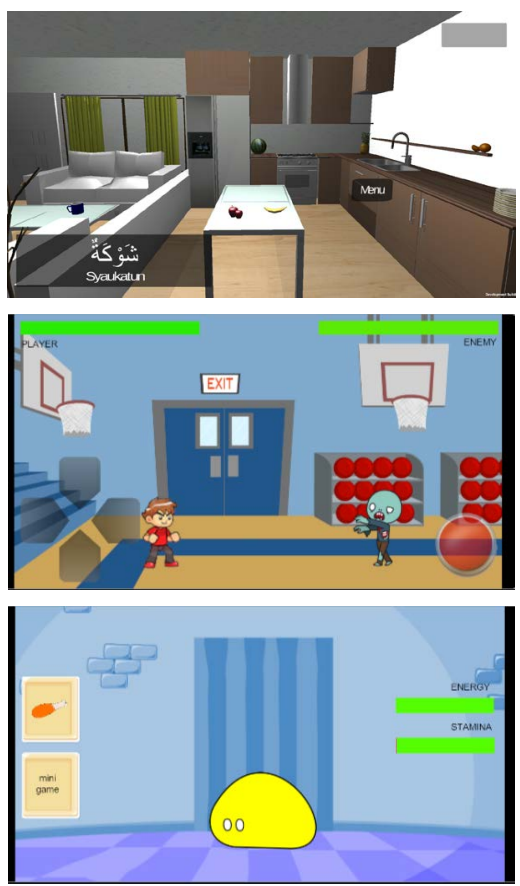

Gambar 3. Gameplay kelompok kedua. Atas: game FPS, tengah: game fighting, bawah: game virtual life

\section{Hasil}

\section{A. Pengujian kelompok pertama}

Pada kelompok pertama diambil 32 data pengguna yang melakukan pengujian terhadap game edukasi bahasa Arab. Rata-rata perubahan nilai pada pengguna dengan game yang menggunakan teknologi realitas virtual adalah 5,83, perubahan nilai yang paling rendah adalah 0 dan perubahan nilai paling tinggi adalah 20. Rata-rata perubahan nilai pengguna dengan game tanpa menggunakan teknologi realitas virtual adalah 8,75 , perubahan nilai yang paling rendah adalah 0 dan perubahan nilai yang paling tinggi adalah 26,67. Hasil analisis tersebut dapat dilihat pada Tabel 4.

Pada analisis ANOVA satu arah, didapatkan hasil signifikansi 0.169716. Nilai tersebut lebih besar daripada nilai signifikansi $(\alpha)$ yang bernilai 0,05 . Sehingga hasil signifikansi analisis kelompok pertama adalah 0.169716 $>0,05$ dan dapat diambil kesimpulan bahwa $\mathrm{H}_{0}$ diterima, yaitu tidak ada perbedaan yang signifikan pada perubahan nilai pengguna antara game yang menggunakan teknologi realitas virtual dan game yang tidak menggunakan teknologi realitas virtual. Hasil analisis uji ANOVA pada kelompok pertama dapat dilihat pada Tabel 4.

\section{B. Pengujian kelompok kedua}

Pengujian kelompok kedua dilakukan pada 30 orang perngguna dengan komposisi 15 orang laki-laki dan 15 orang perempuan. Analisis deskriptif pada kelompok kedua didapatkan rata-rata perubahan nilai pada jenis game FPS sebesar 13,33 untuk pengguna laki-laki, 15,56 untuk pengguna perempuan, dan total rata-rata perubahan nilai sebesar 14,44. Pada jenis game fighting didapatkan ratarata perubahan nilai pengguna laki-laki sebesar 10,67, 
pengguna perempuan sebesar 12,89 , dan total rata-rata perubahan nilai sebesar 11,78. Pada jenis game virtual life, rata-rata perubahan nilai pengguna laki-laki sebesar 13,33, pengguna perempuan 13,33 , dan total rata-rata perubahan nilai sebesar 11,78. Untuk total rata-rata perubahan nilai dari masing-masing jenis kelamin adalah 12,44 untuk pengguna laki-laki, 12,89 untuk pengguna perempuan Hasil analisis deskriptif pada kelompok kedua dapat dilihat pada Tabel 5.

Pada hasil analisis ANOVA kelompok kedua, didapatkan signifikansi pengaruh metode/jenis game yang diujikan terhadap perubahan nilai pengguna, pengaruh jenis kelamin pengguna terhadap perubahan nilai, dan pengaruh kedua faktor (jenis game dan jenis kelamin pengguna) terhadap perubahan nilai. Nilai signifikansi $(\alpha)$ yang ditetapkan pada pengujian tersebut adalah 0,05 .

Untuk faktor jenis game yang diujikan, didapatkan nilai signifikansi 0.516112 . Nilai tersebut lebih besar dari nilai $\alpha$, yaitu $0.516112>0,05$. Sehingga didapatkan kesimpulan untuk menerima $\mathrm{H}_{0}$, yaitu tidak ada pengaruh yang signifikan dari jenis game terhadap perubahan nilai pengguna. Kemudian pada faktor jenis kelamin pengguna, didapatkan nilai signifikansi 0.83875 . Nilai tersebut lebih besar daripada nilai $\alpha$, yaitu $0.83875>0,05$. Sehingga didapatkan kesimpulan hipotesis untuk menerima $\mathrm{H}_{0}$, yaitu tidak ada pengaruh dari jenis kelamin pengguna terhadap perubahan nilai pengujian pengguna. Selain itu juga pengaruh jenis game dan jenis kelamin pengguna didapatkan nilai signifikansi 0.516112. Nilai tersebut lebih besar daripada nilai $\alpha$, yaitu $0.516112>0,05$. Dari nilai signifikansi tersebut didapatkan kesimpulan hipotesis untuk menerima $\mathrm{H}_{0}$, yaitu kedua faktor (jenis kelamin pengguna dan jenis game) tidak saling memiliki pengaruh yang signifikan terhadap perubahan nilai pengguna. Hasil analisis pada kelompok kedua dapat dilihat pada Tabel 6 .

Dari ketiga nilai signifikansi yang didapatkan, maka dapat disimpulkan bahwa faktor jenis game dan jenis kelamin tidak mempengaruhi perubahan nilai pengguna yang diasumsikan sebagai perubahan kemampuan pengguna dalam menguasai perbendaharaan kosakata Bahasa Arab. Begitu pula kedua faktor tersebut tidak saling mempengaruhi terhadap perubahan nilai pengguna.

Tabel 4. Hasil analisis deskriptif kelompok pertama

\begin{tabular}{ccccc}
\hline Kategori & Jumlah data & Jumlah perubahan nilai & Rata-rata perubahan nilai & Variansi \\
\hline VR & 32 & 186.667 & 5.833 & 42.29391 \\
Non VR & 32 & 280 & 8.75 & 98.74552 \\
\hline
\end{tabular}

Tabel 5. Hasil ANOVA kelompok pertama

\begin{tabular}{lcccccc}
\hline \multicolumn{1}{c}{ Sumber variasi } & SS & df & MS & $\boldsymbol{F}_{\text {hitung }}$ & Nilai $\boldsymbol{P}$ & $\boldsymbol{F}_{\text {tabel }}$ \\
\hline Between Groups & 136.1111 & 1 & 136.1111 & 1.930114 & 0.169716 & 3.995887 \\
Within Groups & 4372.222 & 62 & 70.51971 & & & \\
\hline Total & 4508.333 & 63 & & & & \\
\hline
\end{tabular}

Tabel 6. Hasil analisis deskriptif kelompok kedua

\begin{tabular}{|c|c|c|c|c|}
\hline & FPS & Fighting & Virtual life & Total \\
\hline \multicolumn{5}{|l|}{$\mathbf{L}$} \\
\hline Jumlah data & 15 & 15 & 15 & 45 \\
\hline Jumlah perubahan nilai & 200 & 160 & 200 & 560 \\
\hline Rata-rata perubahan nilai & 13.33333 & 10.66667 & 13.33333 & 12.44444 \\
\hline Variansi & 158.7302 & 55.87302 & 114.2857 & 106.2626 \\
\hline \multicolumn{5}{|l|}{$\mathbf{P}$} \\
\hline Jumlah data & 15 & 15 & 15 & 45 \\
\hline Jumlah perubahan nilai & 233.3333 & 193.3333 & 153.3333 & 580 \\
\hline Rata-rata perubahan nilai & 15.55556 & 12.88889 & 10.22222 & 12.88889 \\
\hline Variansi & 131.2169 & 53.75661 & 126.1376 & 103.8384 \\
\hline \multicolumn{5}{|l|}{ Total } \\
\hline Jumlah data & 30 & 30 & 30 & \\
\hline Jumlah perubahan nilai & 433.3333 & 353.3333 & 353.3333 & \\
\hline Rata-rata perubahan nilai & 14.44444 & 11.77778 & 11.77778 & \\
\hline Variansi & 141.2516 & 54.20179 & 118.5696 & \\
\hline
\end{tabular}


Tabel 7. Hasil ANOVA kelompok kedua

\begin{tabular}{|c|c|c|c|c|c|c|}
\hline Sumber variasi & SS & df & MS & $F_{\text {hitung }}$ & Nilai $P$ & $F_{\text {tabel }}$ \\
\hline Baris (Jenis Kelamin) & 4.444444 & 1 & 4.444444 & 0.041667 & 0.83875 & 3.954568 \\
\hline Kolom (Jenis game) & 142.2222 & 2 & 71.11111 & 0.666667 & 0.516112 & 3.105157 \\
\hline $\begin{array}{l}\text { Interaksi } \\
\text { (Jenis kelamin } * \text { Jenis game) }\end{array}$ & 142.2222 & 2 & 71.11111 & 0.666667 & 0.516112 & 3.105157 \\
\hline Within & 8960 & 84 & 106.6667 & & & \\
\hline Total & 9248.889 & 89 & & & & \\
\hline
\end{tabular}

\section{Diskusi}

Hasil pengujian menunjukkan bahwa pada kelompok pertama, rata-rata perubahan nilai pada pengguna dengan game yang menggunakan teknologi realitas virtual adalah 5,83 dan game tanpa menggunakan teknologi realitas virtual adalah 8,75 . Rata-rata perubahan nilai pengguna pada game dengan teknologi realitas virtual lebih tinggi daripada pengguna pada game tanpa teknologi realitas virtual.

Pada kelompok kedua, perubahan nilai pada jenis game FPS untuk pengguna laki-laki sebesar 13,33, 15,56 untuk pengguna perempuan, dan total rata-rata perubahan nilai sebesar 14,44. Rata-rata perubahan kemampuan pengguna perempuan lebih tinggi daripada pengguna laki-laki. Pada jenis game fighting didapatkan rata-rata perubahan nilai pengguna laki-laki sebesar 10,67 , pengguna perempuan sebesar 12,89 , dan total ratarata perubahan nilai sebesar 11,78 . Rata-rata perubahan kemampuan pengguna perempuan lebih tinggi daripada kemampuan laki-laki pada game fighting. Pada jenis game virtual life, rata-rata perubahan nilai pengguna lakilaki sebesar 13,33, pengguna perempuan 10,22, dan total rata-rata perubahan nilai sebesar 11,78. Rata-rata perubahan kemampuan pengguna laki-laki lebih tinggi daripada pengguna perempuan untuk game jenis virtual life. Untuk total rata-rata perubahan nilai dari masingmasing jenis kelamin adalah 12,44 untuk pengguna lakilaki, 12,89 untuk pengguna perempuan, sehingga secara total perubahan kemampuan pengguna perempuan lebih tinggi daripada perubahan pengguna laki-laki. Perbedaan rata-rata nilai dapat dilihat pada Gambar 4.

Uji hipotesis ANOVA pada kelompok pertama didapatkan hasil signifikansi 0.169716 dan dapat diambil kesimpulan bahwa $\mathrm{H}_{0}$ diterima, yaitu tidak ada perbedaan yang signifikan pada perubahan nilai pengguna antara game yang menggunakan teknologi realitas virtual dan game yang tidak menggunakan teknologi realitas virtual.

Kemudian pada uji hipotesis ANOVA kelompok kedua, didapatkan hasil bahwa untuk faktor jenis game yang diujikan, didapatkan nilai signifikansi 0.83875 . Sehingga didapatkan kesimpulan untuk menerima $\mathrm{H}_{0}$, yaitu tidak ada pengaruh yang signifikan dari jenis game terhadap perubahan nilai pengguna. Kemudian pada faktor jenis kelamin pengguna, didapatkan nilai signifikansi 0.516112 . Kesimpulan hipotesis kedua tersebut adalah menerima $\mathrm{H}_{0}$, yaitu tidak ada pengaruh dari jenis kelamin pengguna terhadap perubahan nilai pengujian pengguna. Selain itu juga pengaruh jenis game dan jenis kelamin pengguna didapatkan nilai signifikansi 0.516112. Dari nilai signifikansi tersebut didapatkan kesimpulan hipotesis untuk menerima $\mathrm{H}_{0}$, yaitu kedua faktor (jenis kelamin pengguna dan jenis game) tidak saling memiliki pengaruh yang signifikan terhadap perubahan nilai pengguna.
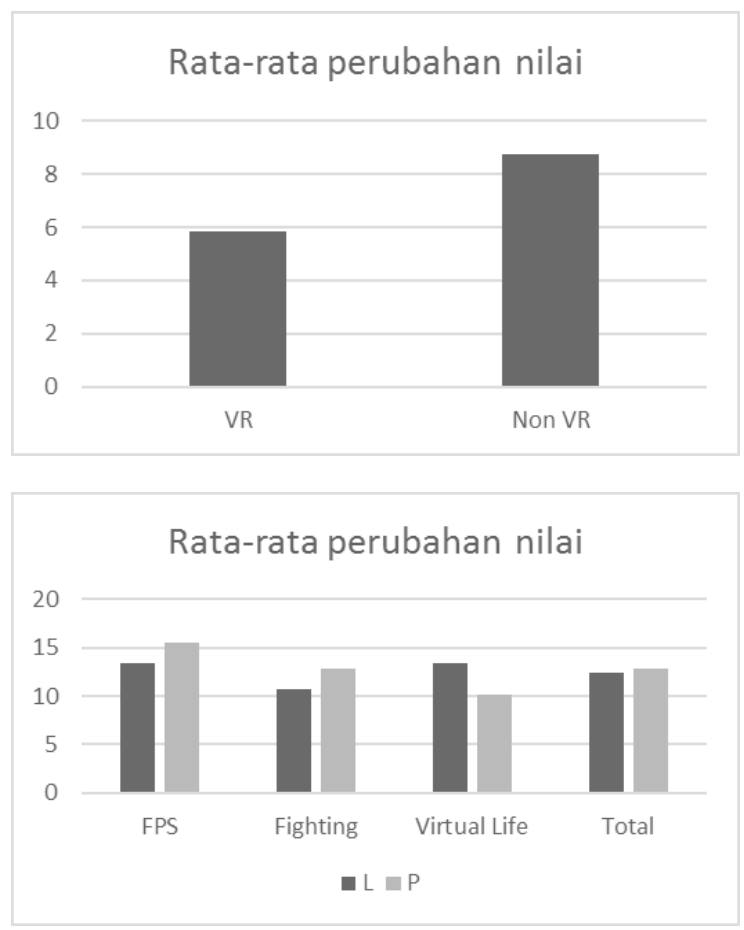

Gambar 4. Grafik perbandingan rata-rata nilai pengguna

\section{Kesimpulan}

Hasil penelitian menunjukkan bahwa pada kelompok pertama, yaitu kelompok yang mengujikan game dengan teknologi realitas virtual dan tanpa teknologi realitas virtual, rata-rata perubahan nilai pengguna pada game dengan teknologi realitas virtual lebih tinggi daripada game tanpa teknologi realitas virtual. Hasil uji hipotesis ANOVA menunjukkan bahwa teknologi yang digunakan tidak berpengaruh secara signifikan terhadap perubahan nilai pengguna, namun tetap terdapat perbedaan antara pengguna yang mengujikan game dengan realitas virtual dan tanpa realitas virtual.

Pada kelompok kedua, pengguna perempuan memiliki perubahan nilai yang lebih besar dibandingkan pengguna laki-laki yang mengujikan game FPS. Pengguna 
laki-laki memiliki perubahan nilai yang lebih besar dibandingkan pengguna perempuan yang mengujikan game fighting dan virtual life. Secara rata-rata total, perubahan nilai pengguna laki-laki lebih besar daripada perubahan nilai pengguna perempuan. Hasil uji hipotesis ANOVA menunjukkan bahwa faktor jenis game, faktor jenis kelamin pengguna, dan hubungan kedua faktor tersebut tidak berpengaruh secara signifikan terhadap perubahan kemampuan pengguna dalam menguasai perbendaharaan kosakata bahasa Arab.

Untuk pengembangan penelitian selanjutnya, disarankan beberapa hal, yaitu pada pengujian diharapkan untuk mengujikan kepada pengguna dengan jumlah yang lebih besar, agar didapatkan data perkembangan kemampuan pengguna yang lebih baik. Selain itu, perlakuan yang diberikan kepada masingmasing pengguna dapat dilakukan berkali-kali sehingga dapat meningkatkan kemampuan lebih baik dan dapat menghasilkan signifikansi pengujian yang dilakukan. Kemudian untuk topik edukasi bahasa Arab, masih banyak peluang untuk dikembangkan, karena bahasa tidak hanya pada kosakata, namun terdapat topik tentang susunan kalimat, sinonim, kaidah penulisan, dan sebagainya. Jenis game yang diteliti juga dapat dikembangkan, agar dapat mendukung pengajaran yang memanfaatkan teknologi yang berkembang, untuk mempermudah siswa dalam mendalami ilmu yang dipelajari.

\section{Daftar Pustaka}

[1] Entertainment Software Association, "Entertainment Software Association: Industry Facts," 2015. [Online]. Available: http://www. theesa.com/about-esa/industry-facts/. [Accessed 20 February 2016].

[2] P. M. Ruano, C. Sevilla, S. Santini, P. A. Haya, P. Rodríguez and G. M. Sacha, "Designing videogames to improve students' motivation," Computers in Human Behavior, pp. 571-579, 2014.

[3] M. M. Ariffin, A. Oxley and S. Sulaiman, "Evaluating Game-Based Learning Effectiveness in Higher Education," Procedia - Social and Behavioral Sciences, pp. 20-27, 2014.
[4] H. Tüzün, M. Yılmaz-Soylu, T. Karakus, Y. Inal and G. Kizilkaya, "The effects of computer games on primary school students' achievement and motivation in geography learning," Computers \& Education, pp. 68-77, 2009.

[5] N. Rutten, W. R. van Joolingen and J. T. van der Veen, "The learning effects of computer simulations in science education," Computers \& Education, pp. 136153, 2012.

[6] L. Aghlara and N. H. Tamjid, "The effect of digital games on Iranian children's vocabulary retention in foreign language acquisition," in International Conference on Education and Educational Psychology, 2011.

[7] R. M. Yilmaz, "Educational magic toys developed with augmented reality technology for early childhood education," Computers in Human Behavior, pp. 240-248, 2016.

[8] E. Sudarmilah and P. A. Wibowo, "Aplikasi Augmented Reality Game Edukasi untuk Pengenalan Organ Tubuh Manusia," Khazanah Informatika, vol. 2, no. 1, pp. 20-25, 2016.

[9] B. D. Homer, E. O. Hayward, J. Frye and J. L. Plass, "Gender and player characteristics in video game play of preadolescents," Computers in Human Behavior, pp. 1782-1789, 2012.

[10] S. MacKenzie, Human-Computer Interaction: An Empirical Research Perspective, Waltham: Morgan Kaufmann, 2013.

[11] S. Wibirama, "Uji Hipotesis dengan ANOVA (Analysis of Variance)," 2011. [Online]. Available: te.ugm.ac.id/ wibirama/tku115/week10/Modul_ ANOVA_sunu.pdf. [Accessed 27 April 2016]. 